\title{
EVALUATION OF RTH IN REGIONAL SPATIAL PLAN WITH NDVI IN KENDARI CITY
}

\author{
Septianto Aldiansyah ${ }^{1}$, Mangapul Parlindungan Tambunan ${ }^{2}$ \\ 1, 2 Departemen Geography, Faculty of Mathematics and Natural Sciences, Indonesia of University \\ St. Margonda Raya, Pondok Cina, Beji Sub-dstrict, Depok City, West Java 16424 \\ Email corresponding: septianto.aldiansyah@ui.ac.id
}

\begin{tabular}{|c|c|c|}
\hline Submitted: & Accepted: & Published: \\
$27-06-2021$ & $29-06-2021$ & $30-09-2021$ \\
\hline
\end{tabular}

\begin{abstract}
Kendari City is the capital of Southeast Sulawesi Province with a population of 345,110 people. The number of residents can trigger a narrowing of RTH (RTH) due to meeting the need for land over time. RTH in urban areas ideally is 30\% of the total area with $20 \%$ public RTH and $10 \%$ private RTH. This study aims for RTH based on the comparison of the area of the RTH Regional Spatial Plan (RTRW) and the actual RTH, the population, the ability to produce oxygen (O2) and absorption of carbon dioxide $\left(\mathrm{CO}_{2}\right)$ in the actual RTH. This research uses quantitative descriptive research in evaluating RTH. The results showed that public RTH in the RTRW still lacked $6.93 \%$ so that it was still necessary to review the RTRW to meet these needs. The current RTH is also still less than the minimum standard of RTH in Kendari City of $7.01 \%$ in public RTH. If it is accumulated, the current availability of RTH still does not meet the minimum standard of RTH in Kendari City. The availability of oxygen $\left(\mathrm{O}_{2}\right)$ and absorption of carbon dioxide $\left(\mathrm{CO}_{2}\right)$ in Kendari City can still meet the needs of residents in Kendari City.
\end{abstract}

Key words: Regional Spatial Plan (RTRW), RTH public, RTH private, Oxygen $\left(\mathrm{O}_{2}\right)$, Carbon dioxide $\left(\mathrm{CO}_{2}\right)$

\section{INTRODUCTION}

Kendari City is the capital city of Southeast Sulawesi Province, so it is not surprising that population growth continues to increase every year. Based on data from the Central Statistics Agency (BPS) for the City of Kendari in 2021, the population of the city of Kendari until 2020 reach 345,110 people with a population density of 1,270 people $/ \mathrm{km} 2$. The greater population growth will affect the development of the city. The result of this is the narrowing of green open space (RTH).

According to Peraturan Menteri Pekerjaan Umum Number: 05/PRT/M/2008 concerning Provision and Utilization of RTHs in Urban Areas that RTH, is an elongated area/lane and/or clustered, whose use is more open, where plants grow, both those that grow plants naturally or those that are intentionally planted. RTH in an urban area ideally is $30 \%$ of the city area. The 30\% proportion is divided into $20 \%$ public RTH and $10 \%$ private RTH. The existence of RTH is expected to create a balance between the natural environment and the built environment.
The failure of RTH can be seen from the outcomes and impacts caused such as landslides, floods, and the imbalance between the availability of RTH and the built area. The impact received in Kendari City is a side effect of the large rate of conversion of vegetated areas for various land use purposes. Several sub-districts, some of which are protected forest areas, such as Abeli District, Poasia District, Kendari District and West Kendari District have a high level of landslide threat (Saleh et al., 2019). Half of the Kendari City area is also a potential flood area, such as in Kadia District and Kambu District (Gandri et al., 2019). High vegetation cover without paying attention to comfort also indirectly reduces the quality of the urban environment because it does not pay attention to air temperature, humidity and wind speed factors (Santi et al., 2019). The presence of RTH in the middle of urban areas can affect the overall RTH which can be useful in producing oxygen produced by vegetated areas such as forests and urban parks.

Making spatial planning is the right initial solution (Rachmawati et al., 2013). 
However, the increase in the built-up area and the use of land for certain purposes affect the sustainability of the function of the area that is directly protected. The estimated use of Kendari City's built-up land is even predicted to increase to $33.70 \%$ in 2030 (Alwan et al., 2020). This conversion clearly violates the rules in spatial planning regarding forest areas where forest areas are areas that should be preserved.

The current research has looked at the distribution of RTH based on the parameters and objectives of each researcher. The presentation of the RTH evaluation between the actual green space and the RTH from the green space area will be clearer and more interesting in representing the availability of green space spatially than just presenting it in tables or graphs. Based on these problems, this study aims to evaluate RTH based on the comparison of the actual RTH area and the actual RTH, the population, the ability to produce oxygen $\left(\mathrm{O}_{2}\right)$ and absorb carbon dioxide $\left(\mathrm{CO}_{2}\right)$ in the actual RTH.

\section{METHODS}

\section{Research Sites}

The research was conducted in Kendari City, Southeast Sulawesi Province with an absolute location of $03^{\circ} 54^{\prime} 40^{\prime \prime S}$ - $04^{\circ} 5^{\prime} 05^{\prime \prime S}$ and $122^{\circ} 26^{\prime} 33^{\prime \prime E}$ - $122^{\circ} 39^{\prime} 14^{\prime \prime E}$ with a total area of 27491, 24 ha which is divided into 10 subdistricts. Based on data from the Central Statistics Agency (BPS) of Kendari City in 2021, the population of the city of Kendari until 2020 reaches 345,110 people with a population density of 1,270 people/ $\mathrm{km} 2$. The study area can be seen in Figure 1 and the area of each sub-district in Kendari City can be seen in Table. 1

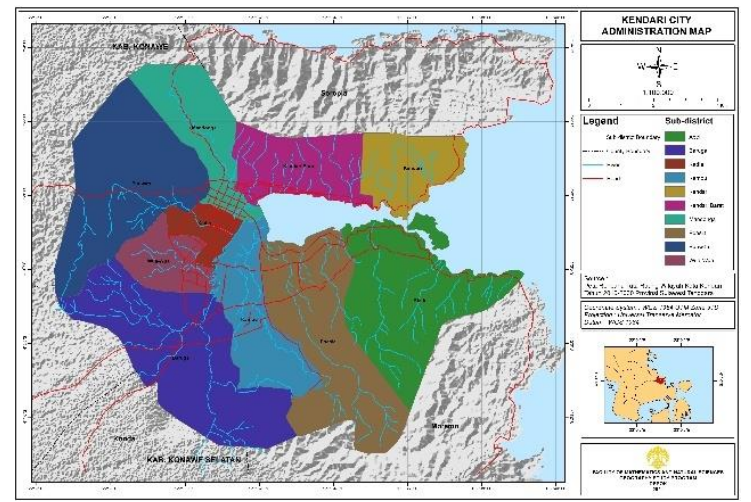

Figure. 1 Kendari City Administration Map (Source: Peta RTRW Kota Kendari 2010-2030)
Table. 1 Sub-district Area in Kendari City

\begin{tabular}{lcc}
\hline Sub-district & Area (ha) & Persentage (\%) \\
\hline Abeli & 4170,26 & 15,17 \\
Baruga & 4912,37 & 17,87 \\
Kadia & 668,45 & 2,43 \\
Kambu & 2243,46 & 8,16 \\
Kendari & 1628,57 & 5,92 \\
Kendari Barat & 2063,52 & 7,51 \\
Mandonga & 2071,86 & 7,54 \\
Poasia & 4188,89 & 15,24 \\
Puuwatu & 4350,68 & 15,83 \\
Wua-Wua & 1193,19 & 4,34
\end{tabular}

Source: Dinas Tata Kota dan Perumahan Kota Kendari

Methods of Data Collection, Processing, and Analysis

This study uses population data, Sentinel-2B imagery data and RTRW 20102030 data. In addition, literature studies from disability and statistical institutions, scientific journals and official websites were also carried out in conducting mathematical and spatial evaluations. The use of data is needed in providing supporting information for the phenomenon under study (Omukuti et al., 2021).

The identification of actual RTH utilizes Sentinel 2B imagery in 2021. The classification of RTH refers to Putra (2012). RTH classification is done based on the Normalize Difference Vegetation Index (NDVI) value. The NDVI value can be used to measure parameters related to vegetation such as green foliage biomass (Febrianti \& Sofan, 2014). The results of NDVI that have been processed are dissolved for medium and high density levels because they represent the type of RTH. RTH evaluation using ArcMAP 10.4 software. The RTH RTRW is intersected with the actual RTH that has been dissolved and the area is calculated. The area of RTH is calculated using the following simple calculation

$R T H(\%)=\frac{\text { The area of each type of } R T H}{\text { Tntal ArRa }} \times 100 \%$

The vegetation density index is determined by the following arithmetic formula:

$N D V I=(N I R-R e d) /(N I R+R e d)$

where NDVI is the BV Value of the Normalized Difference Vegetation Index. NIR or (Near Infra Red) which is the value of the near infrared spectral band and RED is the value of the red spectral band. 
Table. 2 Classification of NDVI values

\begin{tabular}{ccl}
\hline Class & Vegetation Density & \multicolumn{1}{c}{ Type of RTH } \\
\hline$<0$ & Non-Vegetation & $\begin{array}{l}\text { Body of water like river etc } \\
\text { Open land settlements covered with asphalt or paving or } \\
\text { asphalt roads. }\end{array}$ \\
$0-0,10$ & Very low & $\begin{array}{l}\text { Land cover vegetation, such as on dirt roads, empty fields } \\
\text { without asphalt or paving. } \\
\text { Land cover vegetation in the form of coconut plantations, } \\
\text { mixed gardens, grass vegetation, golf courses, reeds. } \\
\text { Forested vegetation }\end{array}$ \\
\hline$, 51-0,70$ & Medium &
\end{tabular}

The evaluation of RTH is carried out based on a comparison of the area of the RTH area of the RTRW and the actual RTH. The comparison of RTH based on area is then presented in the form of a map. Evaluation of the actual need for RTH is carried out based on population, area, types of public RTH and private RTH, production of oxygen $\left(\mathrm{O}_{2}\right)$ and acceptance of carbon dioxide $\left(\mathrm{CO}_{2}\right)$. Evaluation of the need for RTH refers to the provisions of the Regulation of the Minister of Public Works Number: 05/PRT/M/2008 concerning Guidelines for Provision and Utilization of RTH in Urban Areas.

The actual need for green space based on the total population is calculated by the following formula:

RTH needs $=$ Minimum RTH area $\times$ Total Population

The actual need for RTH based on the area is calculated by the following formula:

RTH needs $=$ Total Area $\times$ Minimum Area Condition for RTH

The actual need for RTH based on the types of RTH is calculated using the following formula:

RTH needs $=$ Total Population $\times$ Minimum Standard Area of RTH

The actual need for green space based on the production of oxygen $\left(\mathrm{O}_{2}\right)$ and absorption of carbon dioxide $\left(\mathrm{CO}_{2}\right)$ refers to White et al, (1959). The calculation of the actual green space requirement based on the production of oxygen $\left(\mathrm{O}_{2}\right)$ and absorption of carbon dioxide $\left(\mathrm{CO}_{2}\right)$ refers to Adillasintani (2013) and is calculated by the following formula:

Production $\mathrm{O}_{2}=$ Total Population $\mathrm{x}$ Consumption $\mathrm{O}_{2}$ Absorption $\mathrm{CO}_{2}=$ Total Population $\mathrm{x}$
Production of $\mathrm{CO}_{2}$

Table. 3 Utilization of Trees and RTH for Environmental Quality Improvement

\begin{tabular}{lcc}
\hline \multicolumn{1}{c}{ Description } & 1 Tree & $\begin{array}{c}\text { Area } \\
\text { RTH/1 ha }\end{array}$ \\
\hline Oxygen & 1,7 & 600 \\
Production & kilos/hour & kilos/day \\
Carbon Dioxide & 2,35 & 900 \\
Acceptance & kilos/hour & kilos/day \\
Bonded charcoal & 6 tons & - \\
$\begin{array}{l}\text { Dust filter } \\
\text { Evaporation of }\end{array}$ & - & Up to $85 \%$ \\
water & $500 \mathrm{lt} /$ day & - \\
$\begin{array}{l}\text { Temperature } \\
\text { Drop }\end{array}$ & - & $4^{\circ} \mathrm{C}$ \\
\hline & Source: Adillasintani (2013)
\end{tabular}

\section{RESULTS AND DISCUSSION}

Total population

The population of Kendari City in 2020 reached 345,110 people with a population density of 1,270 people $/ \mathrm{km}^{2}$. This will indirectly affect the development of infrastructure, trade and services, infrastructure and socio-economics which pay less attention to aspects of urban spatial planning, the result of which is the narrowing of RTH. The increase in population will have an impact on the development of infrastructure in urban areas (Arsandi et al., 2017).

\section{RTH in RTRW}

Law Number 26 of 2007 concerning Spatial Planning has required a minimum area of RTH in urban areas of $30 \%$ of the total area consisting of $20 \%$ public RTH and $10 \%$ private RTH. Based on the Kendari City Regulation Number 10 of 2011 concerning the Management of RTH, that which is included in the RTH are 1) roads, road medians, railroads, gas pipelines and pedestrians; 2) city park green areas and lanes; 3) nature tourism park; 4) recreational park; 5) 
residential and residential neighborhood parks; 6) parks for office buildings and commercial buildings; 7) grand forest park; 8) urban forest; 9) protected forest; 10) natural landscapes such as mountains, hills, slopes and valleys; 11) nature reserves; 12) botanical gardens; 13) zoo; 14) public cemetery; 15) sports fields; 16) ceremonial grounds; 17) open parking; 18) urban agricultural land; 19) lines under high voltage (SUTT and SUTET); 20) the boundaries of rivers, beaches, buildings, lakes and swamps; 21) safety lane; 22) airfield buffer zone; and 23) roof garden.

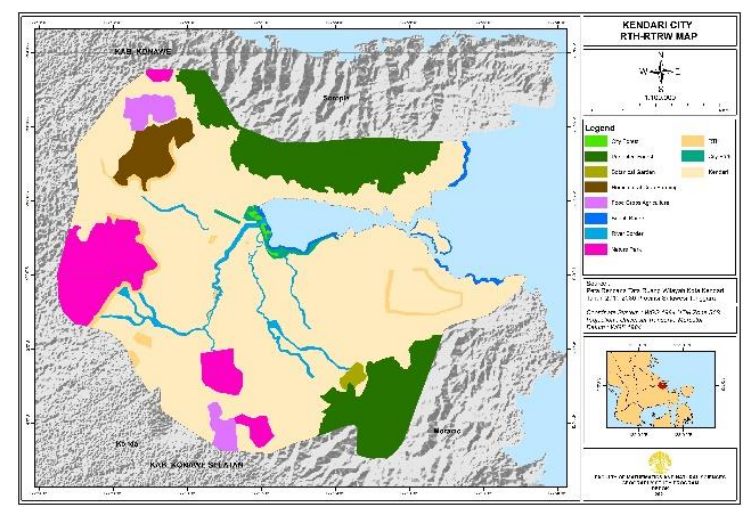

Figure. 2 RTH Plan in RTRW Map

(Source: Peta RTRW Kota Kendari 2010-2030)

Looking at the types of RTH in the Kendari City Regional Regulation Number 10 of 2011 which includes RTH in the Kendari City RTRW consists of public RTH in the form of river borders, beach borders, urban forests, city parks, natural tourism parks, botanical gardens and RTH (Figure 2). Private RTH is in the form of green areas such as protected forests, horticultural crop farming and food crop farming. The area of Kendari City's public RTH is 3869.26 ha or $14.07 \%$ and private RTH is 4657.23 ha or $20.90 \%$ of the total area. It can be seen that the comparison of public RTH which is still lacking $6.93 \%$ and private RTH which has an area that is twice the planned area.

\section{Actual RTH in RTRW}

Based on the classification of RTH using NDVI, it can be seen that RTH is in the vegetation density class $>0.51$. Public RTH is in the medium vegetation density class $(0.51$ $0.70)$ and high vegetation density (> 0.71).
The results of the actual RTH analysis in the RTRW using NDVI can be seen in Figure 3 . Medium vegetation density represents agricultural/plantation area with grass, reed and bush cover. High vegetation density represents forest. The actual area of RTH is the accumulation of medium and high vegetation density. The actual public RTH of Kendari City is 3571.52 ha or $12.99 \%$ and private RTH is 4657.23 ha or $16.94 \%$ of the total area.

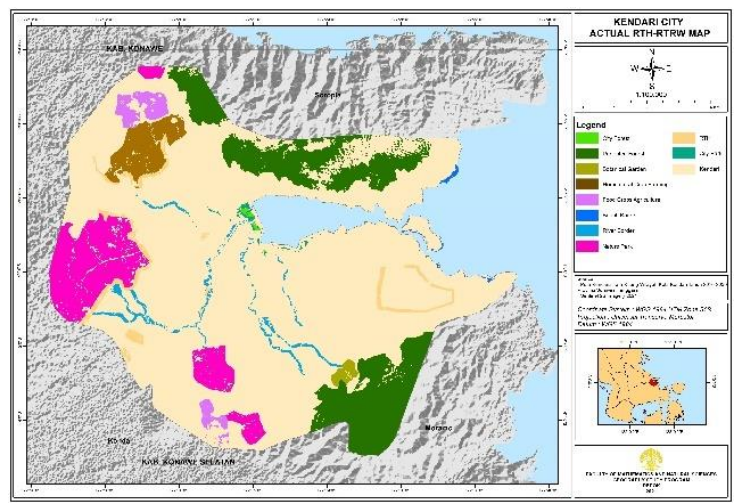

Figure 3 Actual RTH in RTRW Map

(Source: Data Analysis)

This discrepancy reached $3.76 \%$ towards the end of the RTRW period. This means that there will be around 1017.91 ha of forest area to be converted (Alwan et al, 2020).

In the case of Aini et al (2015) in Pacitan City, public RTH consisting of protected areas (green lanes, city parks and forests), cemeteries and tourist lakes has not met the minimum standard of public RTH of $20 \%$ of the total area. The case of Nugroho (2015) which occurred in Sleman District and (Chahya et al., 2019) in Bekasi City also still lacks RTH.

Kendari City as a big city must also pay attention to the pattern of urban development. The pattern of irregular urban development will indirectly change the pattern of green open space. In several big cities such as DKI Jakarta, Bandung City and Jogjakarta City. The city experienced a change in the pattern of RTH due to the changing pattern of urban development, both from concentric to a double center pattern due to changes in land cover (Budiman et al., 2014). 
Table. 4 Planned RTH and actual RTH based on area

\begin{tabular}{clcccc}
\hline \multirow{2}{*}{ RTH } & \multicolumn{1}{c}{ Type of RTH } & \multicolumn{2}{c}{ RTRW } & \multicolumn{2}{c}{ Existing } \\
\cline { 3 - 6 } & & $\begin{array}{c}\text { RTH Area } \\
\text { (ha) }\end{array}$ & $\begin{array}{c}\text { Percentage to } \\
\text { total area (\%) }\end{array}$ & $\begin{array}{c}\text { RTH Area } \\
\text { (ha) }\end{array}$ & $\begin{array}{c}\text { Percentage to } \\
\text { total area (\%) }\end{array}$ \\
\hline \multirow{6}{*}{ Public } & 158,91 & 0,58 & 46,56 & 0,17 \\
& City Park & 43,08 & 0,16 & 27,48 & 0,10 \\
& City Forest & 2258,73 & 8,22 & 2087,04 & 7,59 \\
& Nature Park & 106,72 & 0,39 & 100,55 & 0,37 \\
& Botanical Garden & 565,48 & 2,06 & 465,31 & 1,69 \\
& RTH & 538,65 & 1,96 & 336,17 & 1,22 \\
& River Border & 197,68 & 0,72 & 43,10 & 0,16 \\
& Beach Border & 728,94 & 2,65 & 676,45 & 2,46 \\
& Horticultural Crop Farming & 568,37 & 2,07 & 392,82 & 1,43 \\
Private & Food Crops Agriculture & 4449,65 & 16,19 & 3587,97 & 13,05 \\
\hline & Protected forest & 9616,22 & 34,98 & 7763,44 & 28,24 \\
\hline & Total & & & Source: Data Analysis (2021)
\end{tabular}

Based on Table 4, the forest area has decreased from the area it should have been. The problem of the location of settlements that are not in accordance with the RTRW often occurs in the Murhun Nipa-Nipa forest park area in Mandonga Subdistrict which indirectly gives rise to slum settlements followed by environmental facilities and infrastructure that do not meet eligibility standards or environmental quality. According to the Strategy for the Implementation of Settlement Areas (SPKP) of Kendari City, the problems are in the form of (1) settlements living on the banks of rivers/times; (2) slum settlements; (3) settlements living in protected areas (Tahura Nipa-Nipa): and (4) settlements located in areas prone to landslides and steep slopes.

\section{Evaluation of Actual RTH Needs}

Based on BPS data in 2021, the population of Kendari City is 345,110 people. Kendari City's need for public RTH based on population in 2020 is 6902.2 ha or $25.11 \%$ and private RTH is 3451.1 ha or $12.55 \%$. The projected need for RTH based on population is higher than the actual RTH. This is because the population of Kendari City is not too large, but has a large enough area.

Based on the Kendari City Planning and Housing Office, the actual area of public RTH is 3571.52 ha while private RTH is 4657.23 or 16.94\%. The need for public RTH is 7143.04 or $25.99 \%$ and private RTH is 4657.23 or $16.94 \%$. Based on actual RTH, Kendari City's actual public RTH is 3571.52 ha or $12.99 \%$ and private RTH is 4657.23 ha or $16.94 \%$ of the total area. Public RTH is still lacking $7.01 \%$, but private RTH has exceeded the minimum area with an excess of $6.94 \%$
This is due to the extent of the protected forest area of Kendari City covering an area of 3587.97 ha or $13.05 \%$ of the total area. In some areas, the need for public RTH is still lacking when compared to private RTH (Handayani et al., 2015). If the accumulation of public RTH and private RTH, the city of Kendari is not sufficient for the minimum area of RTH. Based on the total population and area, the total RTH is 5797.85 ha or $21.09 \%$. The difference with the minimum standard area is $8.01 \%$.

There are several problems that complicate the development of RTH in urban areas such as limited funds, limited land availability, land conversion, and lack of community awareness (Cahya et al., 2019). The lack of public RTH should get more attention. The local government should pay special attention to fulfilling the RTH of $30 \%$ of the total area. If the government has not been able to increase the number of $\mathrm{RTH}$, it is better to maintain some areas whose quality and quantity continue to decline. According to Francis (2003:3) that open space problems such as children's playgrounds that are not used, outdated designs, problems with the use of parks that are not grouped so that they interfere with comfort, motorbikes running around, graffiti writing scribbled on walls City Park.

Besides being able to improve services due to the increase in public facilities/infrastructure to support community needs. However, if the conversion of green space land is not handled, it will cause a shortage of neutralizing environmental damage or reduce entertainment and refreshing places for the community (Kusuma \& Sadad, 2017). 
Table. 5 Actual RTH based on Total Population and Area

\begin{tabular}{|c|c|c|c|c|}
\hline RTH & Type of RTH & $\begin{array}{c}\text { Minimum } \\
\text { Standard Area }\end{array}$ & $\begin{array}{c}\text { Area } \\
\text { (ha) }\end{array}$ & $\begin{array}{c}\text { Percentage } \\
\text { to total area } \\
(\%)\end{array}$ \\
\hline \multirow{6}{*}{ Public } & City Park & 0,3 & 103,53 & 0,38 \\
\hline & City Forest & 4,0 & 1380,44 & 5,02 \\
\hline & Nature Park & & \multirow{6}{*}{4313,88} & \multirow{6}{*}{15,69} \\
\hline & Botanical Garden & \multirow{5}{*}{12,5} & & \\
\hline & RTH & & & \\
\hline & $\begin{array}{l}\text { River Border } \\
\text { Beach Border }\end{array}$ & & & \\
\hline & Horticultural Crop Farming & & & \\
\hline Private & $\begin{array}{l}\text { Food Crops Agriculture } \\
\text { Protected forest }\end{array}$ & & & \\
\hline \multicolumn{3}{|c|}{ Total } & 5797,85 & 21,09 \\
\hline
\end{tabular}

Evaluation of the actual need and availability of RTH in the production of oxygen (02) and absorption of carbon dioxide (CO2)

The number of trees in a city determines oxygen production and carbon acceptance. RTH has a very important role in controlling oxygen demand and carbon dioxide acceptance. RTH that has vegetation is able to produce oxygen through the process of photosynthesis and absorb carbon dioxide produced by humans. Different types of plants have different abilities to produce and receive carbon dioxide. According to White at al, (1959) that humans oxidize about 3,000 calories/day from food and use 600 liters of oxygen $\left(840 \mathrm{O}_{2}\right.$ grams/day) and emit about 480 carbon dioxide. Oxygen $\left(\mathrm{O}_{2}\right)$ produced in Kendari City is 2898924 kilos/day. Meanwhile, carbon dioxide $\left(\mathrm{CO}_{2}\right)$ absorbed is 1656528 kilos/day. This means that 1 ha of RTH consisting of at least 1 tree can absorb 900 kilos/day and produce 600 kilos/day oxygen.

Table. 6 Capability of the actual type of RTH in the production of oxygen $\left(\mathrm{O}_{2}\right)$ and absorption of carbon dioxide $\left(\mathrm{CO}_{2}\right)$

\begin{tabular}{clccc}
\hline \multirow{2}{*}{ RTH } & \multicolumn{1}{c}{ Type of RTH } & $\begin{array}{c}\text { Area } \\
\text { (ha) }\end{array}$ & $\begin{array}{c}\text { Production of } \mathrm{O}_{2} \\
\text { (kilos/day) }\end{array}$ & $\begin{array}{c}\text { Absorption of } \\
\mathrm{CO}_{2} \text { (kilos/day) }\end{array}$ \\
\hline Public & City Park & 46,56 & 27937 & 22350 \\
& City Forest & 27,48 & 16487 & 13190 \\
& Nature Park & 2087,04 & 1252222 & 1001777 \\
& Botanical Garden & 100,55 & 60332 & 48266 \\
& RTH & 465,31 & 279184 & 223347 \\
& River Border & 336,17 & 201702 & 161362 \\
& Beach Border & 43,10 & 25862 & 20690 \\
Private & Horticultural Crop Farming & 676,45 & 405867 & 324694 \\
& Food Crops Agriculture & 392,82 & 235693 & 188555 \\
& Protected forest & 3587,97 & 2152779 & 1722223 \\
\hline \multicolumn{2}{c}{ Total } & 7763,44 & 4658067 & 3726453 \\
\hline & & \multicolumn{3}{c}{ Source: Data Analysis (2021) }
\end{tabular}

Based on Table 6, Kendari City's public RTH is able to produce oxygen $\left(\mathrm{O}_{2}\right) 1863727 \mathrm{kilos} /$ day and absorb carbon dioxide $\left(\mathrm{CO}_{2}\right) 1490982$ kilos/day. While the private RTH of Kendari City is able to produce oxygen $\left(\mathrm{O}_{2}\right) 2794339$ kilos/day and absorb carbon dioxide $\left(\mathrm{CO}_{2}\right) 2235472$ kilos/day. If you look at the data that has been analyzed, the actual ability of RTH to produce oxygen and absorb carbon dioxide can be met. When compared with the amount of carbon dioxide that can be absorbed with carbon dioxide from the population, there is a difference of 2,069,925 kilos/day of carbon dioxide that is still able to be absorbed by vegetation. This means that the availability of oxygen production and absorption of carbon dioxide in Kendari City can still meet needs based on population.

\section{CONCLUSION}

The RTH plan in the Kendari City RTRW covers an area of $34.97 \%$ of the total area with the distribution of public RTH covering an area of 3869.26 ha $(14.07 \%)$ and private RTH covering 
an area of 4657.23 ha (20.90\%) of the total area. Public RTH is still lacking $6.93 \%$ so that it is still necessary to review the RTRW to meet these needs.

The actual public RTH of Kendari City is 3571.52 ha or $12.99 \%$ and private RTH is 4657.23 ha or $16.94 \%$ of the total area. RTH is currently still less than the minimum standard of RTH in urban areas in Kendari City.

The availability of oxygen production and absorption of carbon dioxide in Kendari City can still meet needs based on population.

\section{ACKNOWLEDGEMENT}

The researcher would like to thank Parluhutan Manurung, Ph.D who has become a Lecturer for Aplikasi SIG/PJ untuk Evaluasi Pengembangan Wilayah and proposed the theme of this research. Thanks are also conveyed to Dinas Tata Kota dan Perumahan Kota Kendari, Provinsi Sulawesi Tenggara for the data that has been provided.

\section{REFERENCES}

Adillasintani., 2013. Analisis Tingkat Kebutuhan Dan Ketersediaan Ruang Terbuka Hijau Pada Kawasan Perkantoran Di Kota Makasar. Universitas Hasanudin, Makasar.

http://repository.unhas.ac.id/handle/12 $3456789 / 8036$

Alwan, A., Barkey, R. A., \& Syafri, S. (2020). Perubahan Penggunaan Lahan dan Keselarasan Rencana Pola Ruang Di Kota Kendari. Urban and Regional Studies Journal, 3(1), 1-5. https: / /doi.org/10.35965/ursj.v3i1.605

Aini, L. N., Isnawan, B. H., \& Saleh, E. R. (2015). Evaluasi ruang terbuka hijau di Kota Pekanbaru. PLANTA TROPIKA: Jurnal Agrosains (Journal of Agro Science), 3(1), 41-51.

https://doi.org/10.18196/pt.2015.038.4 $1-51$

Arsandi, A. S., Ismiyati, I., \& Hermawan, F. (2017). Dampak Pertumbuhan Penduduk Terhadap Infrastruktur Di Kota Semarang. Jurnal Karya Teknik Sipil, 6(4), 01-14. http://ejournals1.undip.ac.id/index.php/jkts

Badan Pusat Statistik Kota Kendari tahun 2021 Budiman, A., Sulistyantara, B., \& Zain, A. F. (2014). Deteksi perubahan ruang terbuka hijau pada 5 kota besar di Pulau Jawa (Studi kasus: DKI Jakarta, Kota Bandung, Kota Semarang, Kota Jogjakarta, dan Kota Surabaya). Jurnal Lanskap Indonesia, 6(1), 7-15. https://doi.org/10.29244/jli.2014.6.1.715

Cahya, D. L., Widyawati, L. F., \& Ayodhia, F. W. (2019). Evaluasi ketersediaan ruang terbuka hijau di kota Bekasi. Jurnal Planesa (Plenologi).

Febrianti, N., \& Sofan, P. (2014). Ruang terbuka hijau di DKI Jakarta berdasarkan analisis spasial dan spektral data Landsat 8. In Seminar Nasional Penginderaan Jauh (Vol. 2014, pp. 499-504).

Francis, M. (2003). Urban open space: Designing for user needs. Island Press.

Gandri, L., Purwanto, M. Y. J., Sulistyantara, B., \& Zain, A. F. M. (2019). Pemodelan Bahaya Banjir Kawasan Perkotaan (Studi Kasus di Kota Kendari). Jurnal Keteknikan Pertanian, 7(1), 9-16. https://doi.org/10.19028/jtep.07.1.9-16

Handayani, W., Hardiman, G., \& Buchari, I. (2015). Ketersediaan Ruang Terbuka Hijau Publik Kota Pacitan. Jurnal Ilmiah MOMENTUM, 11(2). http://dx.doi.org/10.36499/jim.v11i2.13 87

Kusuma, A. H. S., \& Sadad, A. Pengalihfungsian Lahan Ruang Terbuka Hijau (Taman Kota Jalan Garuda Sakti) Menjadi Rumah Sakit Umum Daerah Kota Pekanbaru (Doctoral dissertation, Riau University).

Nugroho, V. C. (2015). Evaluasi Ruang Terbuka Hijau di Kecamatan Sleman Kabupaten Sleman. PLANTA TROPIKA: Jurnal Agrosains (Journal of Agro Science), $\quad 3(2), \quad 114-121$. https://doi.org/10.18196/pt.2015.048.1 14-121

Omukuti, J., Megaw, A., Barlow, M., Altink, H., \& White, P. (2021). The value of secondary use of data generated by nongovernmental organisations for disaster risk management research: Evidence from the Caribbean. International Journal of Disaster Risk Reduction, 56(January), 102114. https://doi.org/10.1016/j.ijdrr.2021.102 114.

Peraturan Daerah Kota Kendari No. 10 tahun 2011 tentang Pengelolaan Ruang Terbuka Hijau

Peraturan Menteri Pekerjaan Umum Nomor:05/PRT/M/2008 tentang Penyediaan dan Pemanfaatan Ruang Terbuka Hijau Di Kawasan Perkotaan

Putra, E. H. (2012). Analisis Kebutuhan ruang terbuka hijau Berdasarkan Pendekatan Kebutuhan Oksigen Menggunakan Citra Satelit EO-1 ALI (Earth Observer-1 
Advanced Land Imager) di Kota Manado. Earth Observer, 1, 41-54.

Rachmawati, T., Muta'ali, L., \& Santosa, L. W. (2013). Kajian Daya Dukung Bioekologikawasan Puncak Kabupaten Bogor. Majalah Geografi Indonesia, 27(2), 180-197. https: / / doi.org/10.22146/mgi.13430

Saleh, F., Mey, D., \& Salahudin, S. (2019). Kajian Spasial Tingkat Ancaman Bencana Tanah Longsor Kota Kendari. Physical and Social Geography Research Journal, 1(1), 13-22.

Santi, S., Belinda, S., \& Rianty, H. (2019). Identifikasi Iklim Mikro Dan Kenyaman Termal Ruang Terbuka Hijau Di Kendari. NALARs, 18(1), 23-34. https://doi.org/10.24853/nalars.18.1.23 $-34$

Strategi Penyelenggaraan Kawasan Permukiman (SPKP) Kota Kendari. 2019. Record 160 Pengembangan Kawasan Permukiman: Arahan Kebijakan Rencana Induk Sektor, Dokumen Penanganan Kumuh Lainnya: Provinsi Sulawesi Tenggara. Kota Kendari.

White, A., Handler. P. Smith. P. dan Setter. 1959. Principle of Chemistry. Second Edition, Mc Graw Hill Book Company. Inc. Ney York. 